\title{
A new species of Alpaida (Araneae, Araneidae) from Caxiuanã National Forest, Oriental Amazonia, Brazil
}

\author{
Naiara Abrahim ${ }^{1} \&$ Alexandre B. Bonaldo ${ }^{2}$ \\ 1. Programa de Pós-Graduação em Zoologia, Museu Paraense Emílio Goeldi, Caixa Postal 399, 66040-170 Belém, PA, Brazil. \\ (naiabrahim@yahoo.com.br) \\ 2. Coordenação de Zoologia, Museu Paraense Emílio Goeldi, Caixa Postal 399, 66040-170 Belém, PA, Brazil. (bonaldo@museu- \\ goeldi.br)
}

\begin{abstract}
Alpaida guto n. sp. is described based on males and females from State of Pará, Brazil. This species appears to be the most abundant Alpaida O. P.-Cambridge, 1889 species in Caxiuanã National Forest, eastern Amazonia. The males seem to be close to $A$. antonio Levi, 1988 but can be easily distinguished by the terminal apophysis with rounded distal lobe and long, slender basal prong; females differ from those of A. yotoco Levi, 1988 by the median lobe with a basal constriction and by the bilobed median plate.
\end{abstract}

KEYWORDS. Araneidae, Alpaida, Oriental Amazonia, Neotropical Region, Taxonomy.

RESUMO. Uma nova espécie de Alpaida (Araneae, Araneidae) da Floresta Nacional de Caxiuanã, Amazônia Oriental, Brasil. Alpaida guto sp. n. é descrita com base em machos e fêmeas do Estado do Pará, Brasil. Esta parece ser a espécie de Alpaida O. P.-Cambridge, 1889 mais abundante na Floresta Nacional de Caxiuanã, Amazônia Oriental. Os machos assemelham-se aos de A. antonio Levi, 1988 mas podem ser facilmente distinguidos pela apófise terminal com lobo distal arredondado e prolongamento basal longo e delgado; as fêmeas diferem daquelas de A. yotoco Levi, 1988 pelo lobo mediano com uma constrição basal e pela placa mediana bilobada

PALAVRAS-CHAVES. Araneidae, Alpaida, Amazônia Oriental, Região Neotropical, Taxonomia.

The genus Alpaida O. P.-Cambridge, 1889 is composed by diurnal orb-weaver spiders occurring only in Neotropical region. Species of this genus are recognized by the bright, glabrous body; male palp with radix, embolus and terminal apophysis fused; mushroomshaped paramedian apophysis with stalk attached to the conductor. Females are recognized by the shape of the epigynum which is usually transverse and sclerotized, with posterior lips; middle portion drawn out into a triangular lobe or scape; copulatory openings on each side between plate and lips (LEVI, 1988).

LEVI (1988) presented an extensive revision of the genus, redescribing 40 previously known species, which were scattered in various Araneidae genera, and describing 94 new species, totalizing 134 species. Although the author had estimated that the actual richness of the genus could reach 300 species, only two additions to the taxonomy of the genus were made after his revision: LeVI (1992) redescribed A. tullgreni (Caporiacco, 1955), originally proposed in Parawixia F. P.-Cambridge, 1904, and Buckup \& Meyer (1993) described the hitherto unknown male of $A$. scriba (MelloLeITÃo, 1940).

Caxiuanã National Forest is a 333,000 hectares forest reservation in the west margin of Caxiuanã Bay, Upper Anapú River, State of Pará, Brazil. It is composed mainly by tropical dense dry land rain forest (Terra Firme) (LisBOA, 1997; LisBoA et al., 1997). The spider fauna in this area has been intensively sampled thanks to several recent inventory initiatives. These efforts have revealed a rich and poor known Araneidae fauna. To date nearly 80 species of Araneidae were recorded in the study area, nine of which are Alpaida (A. antonio Levi, 1988; $A$. chickeringi Levi, 1988; A. delicata (Keyserling, 1892); A. erythrothorax (Taczanowski, 1873); A. iquitos Levi, 1988; A. simla Levi, 1988; A. tabula (Simon, 1895); A. truncata (Keyserling, 1865); A. urucuca Levi, 1988) (J.A.P. Barreiros, unpublished data; MARTINS \& Lise, 1997). This picture is similar to that found by HöFER \& BRESCOVIT (2001) in "Reserva Florestal Adolpho Ducke", Manaus, Central Amazonia, the most intensively sampled site in Brazilian Amazonia regarding spider fauna. These authors reported 91 species of Araneidae occurring at that reserve, identifying nine Alpaida species among then (A. acuta (Keyserling, 1865); A. bicornuta (Taczanowski, 1878); A. carminea (Taczanowski, 1878); A. delicata; A. negro Levi, 1988; A. tabula; A. trispinosa (Keyserling, 1892); A. truncata; $A$. urucuca). Interestingly, despite the fact that the current number of recorded known Alpaida species is similar in Caxiuanã and Reserva Ducke, only four of these species are known to occur in both sites.

The new species of Alpaida herein described occurs in several localities inside the Caxiuanã National Forest, mainly in the Ferreira Penna Scientific Station and in the PPBio parcel at Caquajó Creek, a tributary of the Anapú River. However, an isolated record in the Metropolitan area of Belém (Santa Barbara Municipality), nearly 400 kilometers from Caxiuanã, is also reported.

\section{MATERIALS AND METHODS}

The specimens examined are deposited in the collections of Museu Paraense Emílio Goeldi (MPEG), Belém, Pará (Curator: A. B. Bonaldo) and Museu de Ciências Naturais (MCN), Fundação Zoobotânica do Rio Grande do Sul, Porto Alegre, Rio Grande do Sul (Curator: 
E. H. Buckup). The methods used to make illustrations and measurements were the same used by LEVI (1985, 1988). The palp was illustrated in mesal view and the epigynum in both ventral and posterior views. All measurements are in millimeters.

\section{Alpaida guto n. sp.}

(Figs. 1-4)

Type-material. Holotype. BRAZIL, Pará: Melgaço, Floresta Nacional de Caxiuanã (Parcela PPBio, Igarapé Caquajó, 01'57'38.9"S, 5136'45.3"W), O’, 09.V.2005, C. A. Lopes col. (MPEG 5241). Paratypes. BRAZIL, Pará: Melgaço, Floresta Nacional de Caxiuanã, (Parcela PPBio, Igarapé Caquajó, 01'57'38.9'S, 51'36'45.3"W), 29, 10-12.V.2005, D. F. Candiani col. (MPEG 5248, 5249); (Estação Científica Ferreira Penna, Parcela Estação, 01 ${ }^{\circ} 44^{\prime} 22.7^{\prime \prime}$ S, 51 $\left.{ }^{\circ} 27^{\prime} 27.9^{\prime \prime} \mathrm{W}\right)$, O', 13.II.2002 $^{\prime}$ (MPEG 5247); 9 , 25.III.2002 (MPEG 5251); 29, 05-06.IV.2002 (MPEG 5242, MCN 43159), A. B. Bonaldo col.; 30', 0910.IV.2002, M. G. Silva Jr. col. (MPEG 5244, 5246, MCN 43158); $0^{2}$, 06.IV.2002, I. Furtado col. (MPEG 05243); $\sigma^{2}$, + , 05.IV.2002, J. A. P. Barreiros col. (MPEG 5245); ㅇ, 05.IV.2002, R. Trindade col. (MPEG 5250).
Etymology. The specific name is patronym in honor of arachnologist José Augusto Pereira Barreiros, nicknamed Guto (in memoriam), who collected some of the specimens studied here as well as several other spider samples in Caxiuanã National Forest.

Diagnosis. The male of Alpaida guto n. sp. resembles those tentatively attributed by LEVI (1988) to A. antonio Levi, 1988 by the terminal apophysis with distal lobe strongly folded, projected beyond the cymbium (see LEVI, 1988, figs. 396, 397); differs by the terminal apophysis with larger, rounded distal lobe and long, slender basal prong; median apophysis wider, duckshaped (Fig. 1). Females are similar to those of $A$. yotoco Levi, 1988 by the large epigynal lips which are wider than median plate in posterior view (see LEVI, 1988, figs. 579$582)$; differs by the median lobe with a basal constriction (Fig. 3) and by the bilobed median plate (Fig. 4).

Description. Male (Holotype): Carapace, legs, endites and chelicera yellow. Eyes ringed in black. Sternum yellowish with median black longitudinal line.
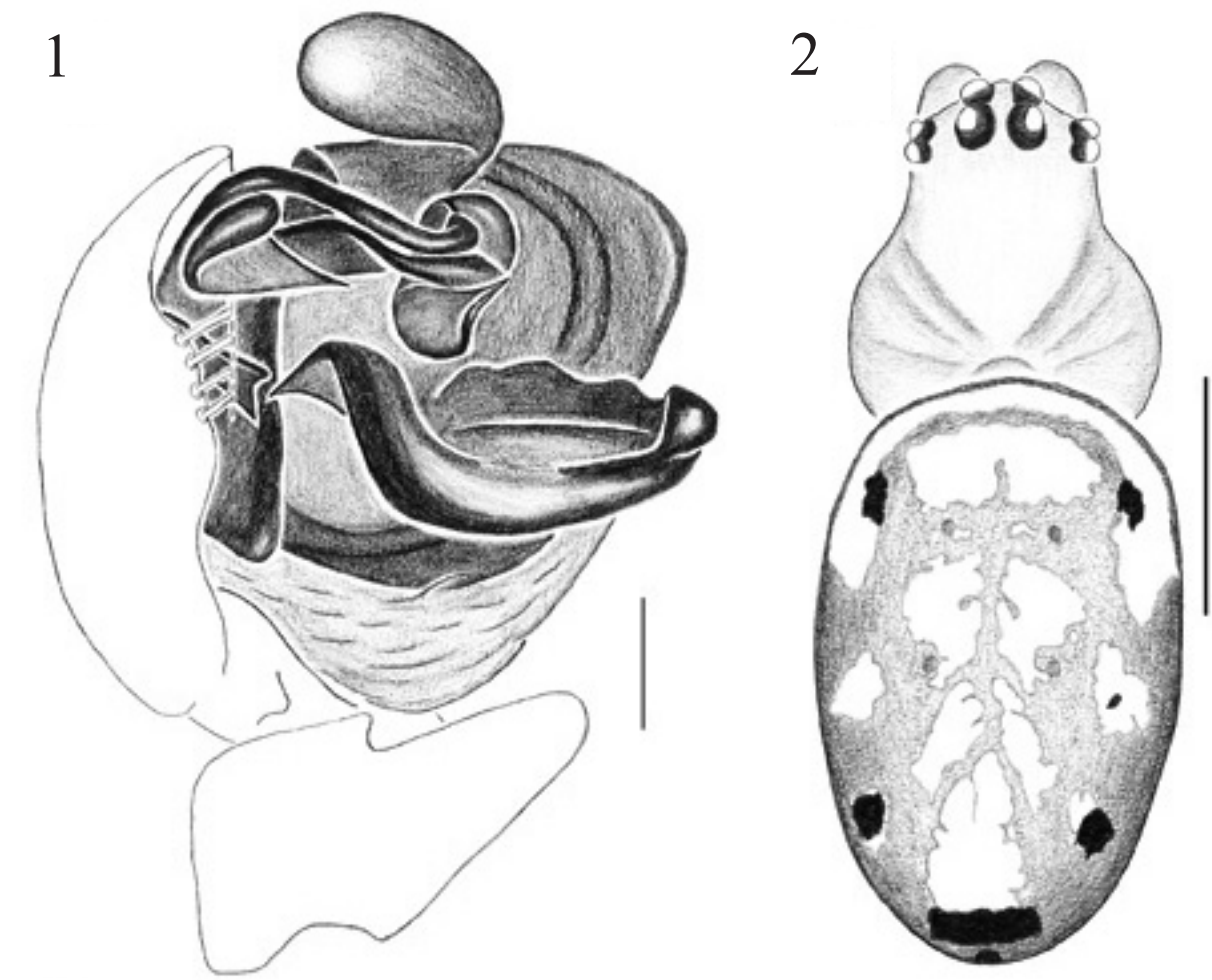

3

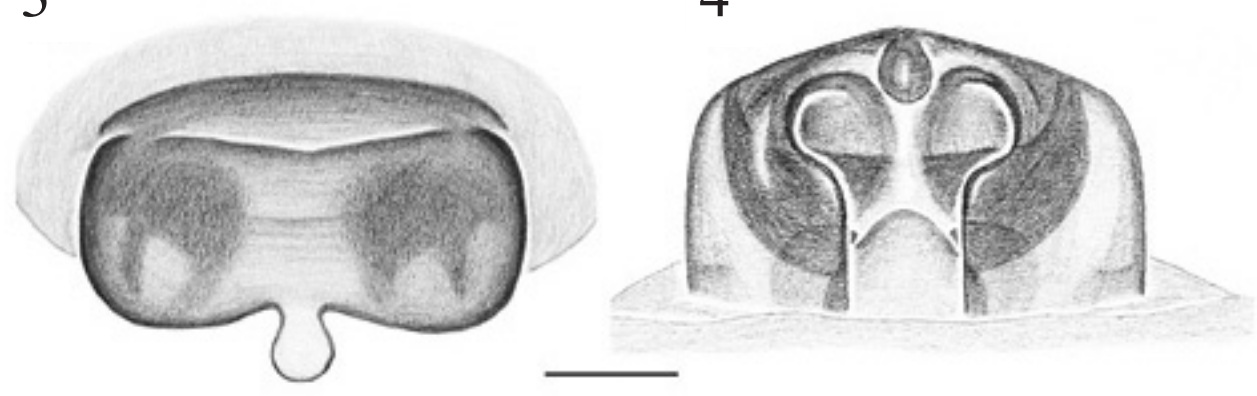

Figs. 1-4. Alpaida guto n. sp. 1, male palp, mesal view (cymbial macrosetae only partially represented); 2, female's cephalotorax and abdomen, dorsal view; 3, female epigynum, ventral view; 4, same, posterior view. Scales: Figs. 1, 3, 4, 0.1 mm; Fig. 2, $1.0 \mathrm{~mm}$. 
Dorsum of abdomen yellow with two lateral pairs of black patches and posterior black mark; venter yellowhish without pigment except for a median dusky patch. Palp with four long macrosetae on mesal edge of cymbium, extended towards the embolus tip and conductor. Total length 3.0. Carapace 1.6 long, 1.2 wide. First leg: femur 1.9; patella and tibia 2.2; metatarsus 1.6 ; tarsus 0.6. Second patella and tibia 1.7; third 1.1; fourth 1.5.

Female (Paratype MPEG 5242): Color as in male, except for the presence of white patches in the dorsum of abdomen, between the two lateral pairs of black patches and posterior black mark (Fig. 2); venter yellowhish, without marks. Total length 3.6. Carapace 1.5 long, 1.2 wide. First leg: femur 1.8; patella and tibia 1.9; metatarsus 1.4 ; tarsus 0.6 . Second patella and tibia 1.6 ; third 1.0 ; fourth 1.6.

Variation. Males $(n=10)$ : total length, 2.8 - 3.9; females $(n=10)$ : total length, 3.5 - 4.8. Males may present the same dorsal color pattern in the abdomen as in females, depending on the amount of deposited guanine; the macrosetae number on mesal edge of cymbium varies (3 at 5). Some female present a median dusky patch on the venter of abdomen.

Other material examined. BRAZIL, Pará: Melgaço, Floresta Nacional de Caxiuanã (Parcela PPBio, 01 ${ }^{\circ} 57^{\prime} 38.9^{\prime \prime} S$, $\left.51^{\circ} 36^{\prime} 45.3^{\prime \prime} \mathrm{W}\right), 2$, $0^{7}, 10 . \mathrm{V} .2005$, C. A. Lopes col. (MPEG 5255, 5268); 29, 09.V.2005, D. F. Candiani col. (MPEG 5265, 5267); O', 09.V.2005, J. A. P. Barreiros col. (MPEG 5266); (Estação Científica Ferreira Penna, Parcela Estação, $01^{\circ} 44^{\prime} 22.7^{\prime \prime} \mathrm{S}, 51^{\circ} 27^{\prime} 27.9^{\prime \prime} \mathrm{W}$ ), ㅇ, 07-13.II.2002 (MPEG 5254), O', 29, 06-10.IV.2002, (MPEG 5256, 5258, 5270), A. B. Bonaldo col.; $0^{2}, 29,09-10 . I V .2002$, C. Trinca col. (MPEG 5262, 5269, 5259); 29, 10.IV.2002, M. G. Silva Jr col. (MPEG 5260, 5263); , 11-20.VII.1998, B. Silva col. (MPEG 05252); ९, 16.XI.2001, F. Aires col. (MPEG 5253); ㅇ, 06.IV.2002, R. Trindade col. (MPEG 5257); 9 , 09.IV.2002, E. Hernandez col. (MPEG 5261); ㅇ, 13.VII.2002, J. Sifuentes col. (MPEG 5271); (Estação Científica Ferreira Penna, Parcela Puraquequara, $01^{\circ} 44^{\prime} 60.3$ 'S, 51 $28^{\circ} 38.6^{\prime}$ W), ,, 10. VII.2002, L. F. Montag col. (MPEG 5264); Santa Bárbara (Denpasa), O', 21.IV.2002, D. R. Santos-Souza col. (MPEG 4657).

Natural History. Alpaida guto n. sp. appears to be the most abundant Alpaida species in Caxiuanã National
Forest, reaching nearly $50 \%$ of all adult Alpaida specimens so far obtained in the PPBio parcel; considering all samples available from Caxiuanã Natural Forest, this species reaches nearly $20 \%$ of all Araneidae specimens collected in this area until now. It has been collected in nearly two meters high trees and small bushes, mainly during the rainy period, using beating tray, sweep net and manual nocturnal looking up collecting methods.

Acknowledgements. José Augusto Pereira Barreiros (MPEG) compiled the available natural history information. We thank Erica Helena Buckup (MCN) for useful suggestions to this paper. Collecting support was provided by the Multitaxonomic Inventory of Caxiuanã National Forest (PNOPG/ CNPq) and Programa de Pesquisa em Biodiversidade - MPEG/ MCT (PPBio). Our work was supported by PPBio through a $\mathrm{CNPq}$ undergraduate grant to the first author (ITI-A grant \# $182988 / 2005-8)$. The second author was supported by $\mathrm{CNPq}$ (PQ grant \#303591/2006-3).

\section{REFERENCES}

Buckup, E. H. \& Meyer, A. C. 1993. Sobre o macho de Alpaida scriba (ARANEAE, ARANEIDAE). Revista Brasileira de Entomologia 37(2):353-354.

Höfer, H. \& Brescovit, A. D. 2001. Species and guild structure of a Neotropical spider assemblage (Araneae) from Reserva Ducke, Amazonas, Brazil. Andrias 15:99-119.

Levi, H. W. 1985. The Spiny Orb-Weaver Genera Micrathena and Chaetacis (Araneae: Araneidae). Bulletin of the Museum of Comparative Zoology 150(8):429-618. 1988. The Neotropical Orb-Weaving Spider of the Genus Alpaida (Araneae: Araneidae). Bulletin of the Museum of Comparative Zoology 151(7):365-487.

1992. American Neoscona and Corrections to Previus Revisions of Neotropical Orb-Weavers (Araneae: Araneidae). Psyche 99(2-3):221-239.

Lisboa, P. L. B. 1997. A Estação Científica Ferreira Penna/ ECFPn. In: LisboA, P. L. B. org. Caxiuanã. Belém, Museu Paraense Emílio Goeldi. p.23-49.

Lisboa, P. L. B.; Silva, A. S. L. \& Almeida, S. S. 1997. Florística e estrutura dos ambientes. In: LisBoA, P. L. B. org. Caxiuanã. Belém, Museu Paraense Emílio Goeldi. p.163-193.

Martins, M. B. \& Lise, A. 1997. As Aranhas. In: Lisboa, P. org. Caxiuanã. Belém, Museu Paraense Emílio Goeldi. p.381-388.

Recebido em abril de 2007. Aceito em abril de 2008. ISSN 0073-4721

Artigo disponível em: www.scielo.br/isz 